\title{
Difficulties for Mothers: Home Care of Babies Born Preterm
}

\author{
Anneler için Zorluklar: Evde Prematüre Bebek Bakımı
}

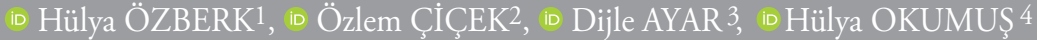

${ }^{1}$ Dokuz Eylül University, Faculty of Nursing, Department of Women's Health Nursing, İzmir, Turkey

2̇̇zmir Bakırçay University, Faculty of Health Sciences, Department of Women's Health Nursing, İzmir, Turkey

${ }_{3}^{3}$ Dokuz Eylül University, Faculty of Nursing, Department of Child Health and Illness Nursing, İzmir, Turkey

${ }^{4}$ Dokuz Eylül University, Faculty of Nursing, Department of Women's Health Nursing, İzmir, Turkey

\begin{abstract}
Mothers who had preterm labor were expected to face difficulties with baby care during the postnatal period. This study aimed to review studies on difficulties experienced by mothers who had premature labor regarding childcare at home during the postnatal period. The literature review was carried out between 2000 and 2019 in databases of PubMed, Medline, CINAHL, Cochrane library, ULAKBIM, Google Scholar, and EMBASE. Mothers who had preterm labor experienced difficulties with diaper use, bathing, umbilical cord care, baby feeding, skin-to-skin contact, and recognition of newborn crying. Therefore, mothers need the support of health professionals for the health status of the newborn and their lack of self-confidence regarding baby care. However, the lack of home care guidelines leaves mothers helpless in meeting these needs. Mothers should be ready for the care of babies born preterm. For this reason, mothers who had preterm labor should be informed about the potential difficulties during their stay in the hospital. Mothers also need to be educated about the care of infants born preterm in the postnatal period. Thus, mothers can experience the home care process positively by becoming fully prepared to take the responsibility for home care. Developing clinical guidelines for postnatal care of babies born preterm can help reduce the concerns of mothers, shorten hospital stay, and reduce morbidity risks.
\end{abstract}

Keywords: Preterm labor, prematurity, baby care, difficulties

\section{ÖZ}

Erken doğum yapan annelerin doğum sonu süreçte bebek bakımı konusunda güçlüklerle karşılaşmaktadırlar. Bu derlemede, erken doğum yapan annelerin doğum sonu dönemde bebeklerinin evde bakımı konusunda yaşadıkları güçlükleri incelemektir. Literatür taraması 2000-2019 yılları arasında PubMed, Medline, CINAHL, Cochrane kütüphanesi, ULAKBİM, Google Akademik ve Elseiver'in EMBASE veri tabanları kullanılarak yapılmıştır. Erken doğum yapan anneler, bebek bezi kullanma, banyo, göbek kordonu bakımı, bebek beslenmesi, ten tene temas, yenidoğan ağlamalarının tanınması konusunda zorluklar yaşamaktadırlar. $\mathrm{Bu}$ nedenle anneler, yenidoğanın sağlık durumu, bebeğin bakımında öz güven eksikliği ve sağlık profesyonellerine ihtiyaç duyma gibi konularda desteğe ihtiyaç duymaktadırlar. Ancak, evde bakım rehberlerinin olmaması annelerin bu ihtiyaçlarının karşılanamamasına neden olmaktadır. Prematüre bebeklerin bakımı için annelerin hazır olmaları gerekmektedir. Bu nedenle erken doğum tehdidi olan annelere hastanede kaldıkları süre içerisinde, yaşadıkları ya da daha sonra yaşayabilecekleri güçlüklere ilişkin eğitimler ve bilgilendirmeler yapılmalıdır. Annelerin prematür bebek bakımı ile ilgili doğum sonu dönemde de bilgilendirilmeye gereksinimleri vardır. Böylelikle anneler evde bakım sorumluluğunu tam olarak üstlenmeye hazır hale gelerek evde bakım sürecini olumlu yönde deneyimleyebilir. Prematüre bebeklerin doğum sonu bakımları ile ilgili klinik rehberlerinin geliştirilmesi, annelerin endişelerinin azaltılması, hastanede kalış süresinin kısaltılması ve morbidite risklerini azaltmada fayda sağlayabilir.

Anahtar Sözcükler: Erken doğum, prematürite, bebek bakımı, güçlükler
Address for Correspondence: Hülya ÖZBERK, Dokuz Eylül University, Faculty of Nursing, Department of Women's Health Nursing, İzmir, Turkey

E-mail: hulya.ozberk@deu.edu.tr ORCID ID: orcid.org/0000-0002-0902-7037
Received: 11.02 .2020

Accepted: 15.01.2021

Cite this article as: Özberk H, Çiçek Ö, Ayar D, Okumuş H. Difficulties for Mothers: Home Care of Babies Born Preterm. Bezmialem Science 2021;9(4):498-502. 


\section{Introduction}

A normal pregnancy lasts approximately 40 weeks, and infants born before the $37^{\text {th }}$ gestational week are defined as "preterm" or "premature" $(1,2)$. According to the World Health Organization (WHO), preterm babies are classified as extremely preterm $\left(<28^{\text {th }}\right.$ gestational week), very preterm $\left(28^{\text {th }}-32^{\text {th }}\right.$ gestational week $)$, and moderate to late preterm $\left(32^{\text {th }}-37^{\text {th }}\right.$ gestational week) (2).

According to the WHO, nearly 15 million babies are born preterm each year, and this number is increasing annually (2). Mothers hospitalized in maternity wards with a diagnosis of threatened preterm labor are most commonly anxious about infant care (36). Therefore, mothers expect support from nurses for pregnancy care and postnatal home care of the baby (7). Mothers diagnosed with preterm labor should be educated starting from the onset of gestation, including the neonatal intensive care unit (NICU) process if the baby requires intensive care after the birth, to the discharge process. Moreover, comprehensive home care plans are needed, support services should be determined, and continuity of care should be ensured and maintained $(8,9)$. This raises the issue of the need for evidence-based care guidelines that will support parents and eliminate their anxieties so that home care of the baby born preterm can be maintained appropriately.

Guidelines for neonatal intensive care and discharge process are mostly related to the treatment and follow-up of infants (10-13). Appropriate guidelines, which involve the family, are needed to provide quality care to babies after discharge. The lack of home care guidelines may cause mothers who had premature births to have difficulty providing care due to the lack of information (14). Therefore, mothers who had premature birth should be informed accurately and adequately about how to care for their babies before discharge (15). Potential difficulties will be prevented when mothers are informed well before discharge.

Nurses have important roles in helping mothers who give premature birth adapt to the home care of the baby after discharge (16). These roles include assessment and direct care of the baby in the hospital and at home (17), training mothers on threatened preterm labor and preterm labor (18), assessment of the home environment, assessment of maternal health (19), and provision of support (17). However, the provision of adequate information about home care of preterm babies and extension of the appropriate care at home is not among the priority options of nurses.

This literature review aimed to reveal the difficulties experienced by mothers who had premature labor regarding infant care at home.

\section{Methods}

The literature review was conducted between 2000 and 2019 in Turkish and English by scanning databases of PubMed, Medline, CINAHL, Cochrane library, ULAKBIM, Google Scholar, and EMBASE. The following keywords were used: "prematurity," "premature infant," "neonatal intensive care," "threatened preterm labor," "premature birth," "discharge from neonatal intensive care," "home care of premature neonatal," "baby care," "challenge," and "difficulty" and their Turkish translations. As a result of the screening, 36 articles that met the inclusion criteria were included in the review. Of these articles, five were about the psychological conditions experienced by mothers with babies in the NICU, six focused on the difficulties of mothers in the care of their babies in the NICU, seven investigated the psychological conditions experienced by mothers because of preterm birth, three reported about the difficulties experienced by healthcare professionals in adapting mothers to the NICU, and 15 presented home care challenges of premature newborns.

\section{Difficulties in Home Care of Preterm Infants}

Mothers who have babies born preterm experience a mixture of happiness and sadness. The reason is the thought of being separated from the baby after birth (20) because the natural process expected to develop between the mother and baby may be disrupted during the treatment of babies born preterm in the NICU, and families may face difficulties related to baby care (21). During the NICU treatment, mothers who had a premature birth are reported to experience difficulties such as concerns about the health of the infant, loss of the maternal role, performing parenting roles for other children, limited visiting hours, transportation barriers, balancing other aspects of family life, and financial problems (22-24). Unclear medical explanations made during the NICU treatment, technological equipment used during the care, and changes in the physical appearance of the baby are quite stressful factors for parents (25). Hemati et al. (26) reported that mothers had difficulty in achieving the home care of the infant after discharge from the NICU, they felt a sense of incompetence regarding breastfeeding, they recognized dependence on the hospital and the nurse, and they felt stressed and anxious constantly. In another study, mothers who had their baby treated in the NICU were found to feel alienated toward their babies while caring for them, and this result suggested that, in addition to mothers' training regarding the treatment and care of the baby in the NICU, interventions for understanding mothers and preventing them from feeling alienated should be arranged (21). Nevertheless, several mothers report that their emotional state is not understood by NICU nurses and physicians (27). This may lead to new problems that need coping for mothers who have infants born preterm and who feel that they are not understood by healthcare workers.

The main difficulties experienced after discharge include feeding and breastfeeding the baby born preterm (28-30). Nutritional problems, sudden death, and hyperbiluribinemia risk are higher in infants discharged from the NICU than infants born at term $(31,32)$. Difficulties such as the need for oxygen therapy as in the hospital, tube feeding, medication administration, and apnea follow-up increase the difficulties experienced by mothers after the baby's discharge from the NICU (14). All these practices bring about an uncertain and anxious process for mothers who had a preterm delivery $(14,33)$. In a study conducted in our country, parents who have infants born preterm were expected to experience a mild level of anxiety. Their anxiety was found to increase especially while counting and assessing the baby's 
breathing (34). These complications, which may occur after discharge, increase the risk of postpartum depression in mothers who had a premature delivery (35). By contrast, the depressed state of women during and after delivery may adversely affect the mental health of their spouses/partners and may disrupt family integrity (36). Moreover, the material losses that occur during the treatment at NICUs may affect family integrity $(37,38)$. In addition to spiritual stress felt after the baby was discharged from the NICU, failure to continue working to care for the baby and failure to find alternative solutions for working conditions such as part-time employment also cause financial stress in families $(37,38)$. Parents may experience psychosocial problems as a result of material and spiritual difficulties.

Recent research presented that the difficulties experienced by mothers are similar. Nurses should address any difficulties before discharge and explain potential problems systematically to mothers in a quiet environment without waiting for the day of discharge. If mothers are facing threatened preterm labor, they should be educated and informed about the expected difficulties during the hospital stay and later upon discharge. Thus, on the day of discharge, missed care services of mothers should be offered gradually without overloading them with information.

\section{Role of Healthcare Professionals in the Home Care of the Baby Born Preterm}

For mothers who had premature delivery, the discharge of the baby from the NICU means going back to their daily lives and making self-decisions about baby care. Mothers state that social (spouse, family, and friends) and professional support is an important factor in adapting to the transition from hospital to home (39). Aldirawi et al. (40) determined that nurses were the leading information sources of mothers after discharge. However, a standard guide on the care offered by nurses, who rank the first in terms of information sources, could not be found.

The qualitative study conducted by Raffray et al. (41) revealed that healthcare workers had difficulty in preparing the family about discharge from the NICU, diaper use, bathing the baby, umbilical cord care, feeding the baby, skin-to-skin contact, and recognition of normal and abnormal states of baby's crying. Batman and Şeker (42) used web-based education given by health personnel to prepare parents for discharge and found that the intervention increased the self-confidence and decreased the anxiety levels of parents with infants born preterm. Moreover, other studies have recommended that health professionals should develop programs that provide both education and support to mothers before discharge (18), nurses should arrange home visits and keep in contact with mothers (14), video conferences should be held so that mothers can contact the nurse when necessary (17), and a written control list should be made for customized training programs and home use as the birth weights of infants born preterm are different from each other and they make heterogeneous groups depending on birth weeks (9).

The recommendations of international associations and related studies are as follows:
- Infants born preterm and mothers should have skin-to-skin contact (43).

- The first home visit to the infant born preterm and the mother who had been discharged should be conducted within $72 \mathrm{~h}$ if possible (44).

- The infant born preterm should be re-visited 1 month after the first home visit, the mother should be followed for breastfeeding, and the infant should be assessed for feeding problems (45).

- The importance of breastfeeding the infant at least 10-12 times or feeding it with formula 8-10 times a day should be explained to the mother (46).

- Mothers should be informed that infants born preterm may be sleeping all the time and should be fed even if asleep (46).

\section{Conclusion}

The NICU treatment of babies born preterm and the discharge period are complex processes due to potential complications. During this process, mothers experience physiological, psychological, and financial difficulties. Mothers' preparation is very important for baby care after discharge. For this reason, mothers should see their babies regularly during NICU treatment until discharge and to participate in the care of the baby so that sustainable home care can be achieved. Nurses should understand, empathize, and empower mothers and facilitate their participation in baby care. Nurses who care for infants born preterm are advised to train families, communicate with them regularly, and place the mother-infant relationship at the center of their care by considering the care needs of the baby and complications that may occur after discharge.

Concerns that mothers will have about baby care in the postnatal period will adversely affect their physiological changes, especially breastfeeding. The support of physicians and nurses for this area, which has some deficiencies, and preparation of guidelines for home care will be a highly valuable service for parents.

Peer-review: Externally peer reviewed.

\section{Authorship Contributions}

Concept: H.Ö., Ö.Ç., D.A., H.O., Design: H.Ö., Ö.Ç., D.A., H.O., Data Collection or Processing: H.Ö., Ö.Ç., D.A., H.O., Analysis or Interpretation: H.Ö., Ö.Ç., D.A., H.O., Literature Search: H.Ö., Ö.Ç., D.A., H.O., Writing: H.Ö., Ö.Ç., D.A., H.O.

Conflict of Interest: No conflict of interest was declared by the authors.

Financial Disclosure: The authors declared that this study received no financial support.

\section{References}

1. The American College of Obstetricians and Gynecologists (ACOG). Extremely Preterm Birth. August 2019 (cited 2019 December 10). Availablefrom: URL: https://www.acog.org/Patients/FAQs/ Extremely-Preterm-Birth?IsMobileSet=false 
2. World Health Organisation (WHO). PretermBirth. February 2018 (cited 2019 December 3). Availablefrom: URL: https://www.who. $\mathrm{int} /$ news-room/fact-sheets/detail/preterm-birth

3. Trumello C, Candelori C, Cofini M,Cimino S, Cerniglia L, Paciello $\mathrm{M}$,et al. Mothers' depression, anxiety, and mental representations after preterm birth: A study during the infant's hospitalization in a neonatal intensive care unit. Front Public Health 2018;6:359.

4. Henderson J, Carson C, Redshaw M. Impact of preterm birth on maternal well-being and women's perceptions of their baby: a population-based survey. BMJ Open 2016;6:e012676.

5. Rodrigues PB, Zambaldi CF, Cantilino A, Sougey EB. Special features of high-risk pregnancies as factors in development of mental distress: a review. Trends Psychiatry Psychother 2016;38:136-40.

6. Oliveira DC, Mandu ENT. Women with high-risk pregnancy: Experiences and perceptions of needs and care. Escola Anna Nery 2015;19:93-101.

7. Guillaume S, Michelin N, Amrani E, Benier B, Durrmeyer X, Lescure $S$, et al. Parents' expectations of staff in the early bonding process with their premature babies in the intensive care setting: a qualitative multicenter study with 60 parents. BMC Pediatr 2013;13:18.

8. González MPO, Espitia EC. Caring for a premature child at home: From fear and doubt to trust.Text Context Nursing, Florianópolis 2014;23:828-35.

9. American Academy of Pediatrics Committee on Fetus and Newborn. Hospital discharge of the high-risk neonate. Pediatrics 2008;122:1119-26.

10. Turkish Society of Neonatology. Premature and sicktermın fant nutrition guide. April 2018 (cited 2019 December 3).Availablefrom: URL: http://www.neonatology.org.tr/wp-content/uploads/2016/12/ premature_rehber_2018.pdf

11. Tschudy MM, Raphael JL, Nehal US, O’Connor KG, Kowalkowski M, Stille CJ. Barriers to Care Coordination and Medical Home Implementation. Pediatrics 2016;138:e20153458.

12. American Academy of Pediatrics Committee on Fetus and Newborn. Hospital discharge of the high-risk neonate. Pediatrics 2008;122:1119-26.

13. McCourt MF, Griffin CM. Comprehensive primary care follow-up for premature infants. J Pediatr Health Care 2000;14:270-9.

14. Lopez GL, Anderson KH, Feutchinger J. Transition of premature infants from hospital to home life. Neonatal Netw 2012;31:207-14.

15. Collins CT, Makrides M, McPhee AJ. Early discharge with home support of gavage feeding for stable preterm infants who have not established full oral feeds. Cochrane Database Syst Rev 2003;(4):CD003743.

16. Broedsgaard A, Wagner L. How to facilitate parents and their premature infant for the transition home. Int Nurs Rev 2005;52:196203.

17. Lindberg B, Axelsson K, Öhrling K. Taking care of their baby at home but with nursing staff as support: the use of video conferencing in providing neonatal support to parents of preterm infants. J Neonatal Nurs 2009; 15:47-55.

18. Willis V. Parenting preemies: a unique program for family support and education after NICU discharge. Adv Neonatal Care 2008;8:221-30.
19. Glazebrook C, Marlow N, Israel C, Croudace T, Johnson S, White IR, et al. Randomised trial of a parenting intervention during neonatal intensive care. Arch Dis Child Fetal Neonatal Ed 2007;92:F438-43.

20. Osorio Galeano SP, Ochoa Marín SC, Semenic S. Preparing for postdischarge care of premature infants: Experiences of parents. Invest Educ Enferm 2017;35:100-6.

21. Williams KG, Patel KT, Stausmire JM, Bridges C, Mathis MW, Barkin JL. The neonatal intensive care unit: Environmental stressors and supports. Int J Environ Res Public Health 2018;15:60.

22. Hall S, Hynan N, Phillips R, Press J, Kenner C, Ryan DJ. Development of program standards for psychosocial support of parents of infants admitted to a neonatal intensive care unit: A national interdisciplinary consensus model. Newborn Infant Nurs Rev 2015;15:24-7.

23. Alkozei A, McMahon E, Lahav A. Stress levels and depressive symptoms in NICU mothers in the early postpartum period. J Matern Fetal Neonatal Med 2014;27:1738-43.

24. Lee HC, Martin-Anderson S, Dudley RA. Clinician perspectives on barriersto and opportunitiesfor skin-to-skin contact forprematureinfants in neonatalintensivecareunits. Breast feed Med 2012;7:79-84.

25. Lefkowitz DS, Baxt C, Evans JR. Prevalence and correlates of posttraumatic stress and postpartum depression in parents of infants in the Neonatal Intensive Care Unit (NICU). J Clin Psychol Med Settings 2010;17:230-7.

26. Hemati Z, Namnabati M, Taleghani F, Sadeghnia A. Mothers' challenges after infants' discharge from neonatal intensive care unit: A qualitative study. Iranian Journal of Neonatology 2017;8:31-6.

27. Mackley AB, Locke RG, Spear ML, Joseph R. Forgotten parent: NICU paternal emotional response. Adv Neonatal Care 2010;10:200-3.

28. Phillips-Pula L, Pickler R, McGrath JM, Brown LF, Dusing SC. Caring for a preterm infant at home: a mother's perspective. J Perinat Neonatal Nurs 2013;27:335-44.

29. Hutchinson SW, Spillett MA, Cronin M. Parent's experiences during their infant's transition from neonatal intensive care unit to home: A qualitative study. Qual Rep 2012;17:1-20.

30. Murdoch MR, Franck LS. Gaining confidence and perspective: A phenomenological study of mothers' lived experiences caring for infants at home after neonatal unit discharge. J Adv Nurs 2011;68:2008-20.

31. Engle WA, Tomashek KM, Wallman C; Committee on Fetus and Newborn, American Academy of Pediatrics. "Late-preterm” infants: a population at risk. Pediatrics 2007;120:1390-401.

32. Blair PS, Platt MW, Smith IJ, Fleming PJ; CESDI SUDI Research Group. Sudden infant death syndrome and sleeping position in pre-term and low birth weight infants: an opportunity for targeted intervention. Arch Dis Child 2006;91:101-6.

33. Hill A. Mothers' Perceptions of child vulnerability in previous pretermin fants. ABNF Journal2015;26:11-6.

34. Çelen R, Taş Arslan F. The anxiety levels of the parents of premature infants and related factors. J Pediatr Res 2017;4:68-74.

35. Hergüner S, Annagür A, Çiçek E, Altunhan H, Örs R. Postpartum depression in mothers of infants with very low birth weight. Nöropsikiyatri Arşivi 2013;50:30-3. 
36. Bradley R, Slade P. A review of mental health problems in fathers following the birth of a child. J Reprod Infant Psychol 2011;29:1942.

37. Wharam JF, Graves AJ, Kozhimannil KB. Navigating the rise of highdeductible health insurance: childbirth in the bronze age. JAMA 2015;313:245-6.

38. Committee on Understanding Premature Birthand Assuring Healthy Outcomes. Pretermbirth: Causes, consequences, andprevention. 2007 (cited 2019 December 12). Availablefrom: URL: http://www. nap.edu/catalog/11622.html

39. Breivold K, Hjaelmhult E, Sjöström-Strand A, Hallström IK. Mothers' experiences after coming home from the hospital with a moderately to late preterm infant - a qualitative study. Scand J Caring Sci 2019;33:632-40.

40. Aldirawi A, El-Khateeb A, Mustafa AA, Abuzerr S. Mothers' knowledge of health caring for premature infants after discharge from neonatal intensive care units in the Gaza Strip, Palestine. Open Journal of Pediatrics 2019;9:239-52.

41. Raffray M, Semenic S, Osorio Galeano S, Ochoa Marín SC. Barriers and facilitators to preparing families with premature infants for discharge home from the neonatal unit. Perceptions of health care providers. Invest Educ Enferm 2014;32:379-92.

42. Batman D, Seker S. Effect of web basededucation which has been applied to parents of premature infants to anxiety and self-confidence (dissertation). Adnan Menderes University. 2014.

43. Reymundo MG, Suazoa JAH, AguilarMJC, Faura FJS, Galiana GG, Peinador YM, et al. Follow-upre commendations for the latepretermin fant. An Pediatr (Barc) 2019;90:318.e1-318.e8.

44. Kuo DZ, Lyle RE, Casey PH, Stille CJ. Care System Redesign for Preterm Children After Discharge From the NICU. Pediatrics 2017;139:e20162969.

45. Noble LM, Okogbule-Wonodi AC, Young MA. ABM clinical protocol \#12: Transitioning the breastfeeding preterm infant from the neonatal intensive care unit to home, revised 2018. Breast feed Med 2018;13:230-6.

46. Méio MDBB, Villela LD, GomesJúnior SCDS, Tovar CM, Moreira MEL. Breast feeding of preterm newborn infants following hospital discharge: follow-up during the first year of life. Cien Saude Colet 2018;23:2403-2412. 